\title{
Propofol Suppresses Proliferation, Migration, Invasion and Promotes Apoptosis by Upregulating microRNA- 140-5p in Gastric Cancer Cells [Retraction]
}

\author{
Zhu F, Li Q, Yang Y, Wang L, Wang J. Onco Targets Ther. \\ 2019;12:10129-10138.
}

The Editor and Publisher of OncoTargets and Therapy wish to retract the published article. It came to the journal's attention that several images with the article appeared to be duplicated, specifically:

- Figure 4B panel MKN45 Control appears to be duplicated with an image from Figure $5 \mathrm{~A}$ panel $\mathrm{NC}$ and Figure 5B panel miR-152 inhibitor from $\mathrm{Lu}$ et al: MicroRNA-152 inhibits tumor cell growth while inducing apoptosis via the transcriptional repression of cathepsin L in gastrointestinal stromal tumor (DOI: 10.3233/CBM-170809).

- Figure 4B panel MKN45 Propofol+miR-140-5p inhibitor appears to be duplicated with an image from Figure 2E panel Migration P10 from Liu et al: Propofol Reduces Epithelial to Mesenchymal
Transition, Invasion and Migration of Gastric Cancer Cells through the MicroRNA-195-5p/Snail Axis (https://www.medscimonit.com/abstract/index/ idArt/920981).

The authors were unable to provide a satisfactory explanation for the alleged duplication nor were they able to provide the original images for the study. The Editor has determined the findings of the study are no longer valid and requested for the article to be retracted.

Our decision-making was informed by our policy on publishing ethics and integrity and the COPE guidelines on retraction.

The retracted article will remain online to maintain the scholarly record, but it will be digitally watermarked on each page as "Retracted".

\section{Publish your work in this journal}

OncoTargets and Therapy is an international, peer-reviewed, open access journal focusing on the pathological basis of all cancers, potential targets for therapy and treatment protocols employed to improve the management of cancer patients. The journal also focuses on the impact of management programs and new therapeutic

agents and protocols on patient perspectives such as quality of life, adherence and satisfaction. The manuscript management system is completely online and includes a very quick and fair peer-review system, which is all easy to use. Visit http://www.dovepress.com/ testimonials.php to read real quotes from published authors. 